\title{
The Use of Wedelia biflora Leaf Extract Influences the Platelet Count in Rats with Contusions
}

\author{
Rinidar $^{1 *}$, Muhammad Isa ${ }^{2}$, Awaluddin ${ }^{3}$ \\ ${ }^{1}$ Laboratory of Pharmacology, Faculty of Veterinary Medicine, Universitas Syiah Kuala, Banda Aceh \\ ${ }^{2}$ Laboratory of Biochemistry, Faculty of Veterinary Medicine, Universitas Syiah Kuala, Banda Aceh \\ ${ }^{3}$ Laboratory of Pathology, Faculty of Veterinary Medicine, Universitas Syiah Kuala, Banda Aceh \\ *Corresponding author. Email: rinidar@unsyiah.ac.id
}

\begin{abstract}
A contusion or bruise occurs when blood vessels are damaged or broken because of a trauma to the skin. The initial phase in responding to a contusion in the body is the entry of platelets into the wound area. This platelet infiltration functions as a hemostasis. This study aimed to determine the effectiveness of Wedelia biflora leaf extract against platelets count in rats with contusion. The research used a completely randomized design (CRD). The experimental animals used were 20 of male rats (Rattus novergicus) randomly assigned into four treatment groups namely rats treated with Wedelia leaves extract of $0 \%(\mathrm{P} 0$, control), $10 \%(\mathrm{P} 1), 20 \%(\mathrm{P} 2)$ and $40 \%(\mathrm{P} 3)$ for 8 days. The whole blood was collected on day 1, 5 and 8 and analyzed using an automatic cell counter. The data were analyzed using ANOVA. The results showed a significant influence $(p<0.05)$ of the treatment and time on the platelet count in rats. A significant relationship was also found between the platelets count and contusion area.
\end{abstract}

Keywords: Contusion, platelet, Wedelia biflora

\section{INTRODUCTION}

Contusions are formed due to the impact of hard objects or repeated blows by blunt objects that hit the soft tissues of the body. They can also occur spontaneously as a result of blood clots disruption or autoimmune. As consequences, the muscle fibers and connective tissue underneath are destroyed but the skin is still intake. The affected area will be bluish, purplish, reddish or blackish in due to red blood cells exit from the leak blood vessels under the skin tissue and accumulate there. Contusions are usually accompanied by swelling (edema), pain, and redness from increased accumulation of red blood cells. The color of changes with the body response and duration. Contusions that already last for 4-5 days have green color. The color turn yellow within the next 7-10 days, and disappeared within 14-15 days. Contusions also become important parts of forensic medicine and medicolegal [1].

Important manifestation of pathophysiological responses to contusions and wounds is microvascular dysfunction that includes activation of vascular endothelial cells, circulating leukocytes and platelet [2]. In the initial phase of inflammation due to tissue damage, there is a leak of blood vessels that drive various elements of blood to the wound site, such as platelets.
This platelet serves as a hemostasis, which clog open vascular (clot) and also secrete the substance vasoconstriction that results in vasoconstriction blood vessels, then there is an endothelial attachment that will close the blood vessels. During the process platelet will degranulate and release some growth factors such as platelet growth factor (PDGF) and transforming growth factor (TGF) [3].

Contusions cause inflammatory reactions as an perform of defense mechanisms. The uncontrolled and persistent inflammatory reaction might cause health problems. These problems are usually treated by giving corticosteroid or non-corticosteroid antiinflamation drugs (NSAIDs). Longterm use of these drugs could cause adverse side effects such as increased the risk of bleeding by changing platelet function negatively [2].

Wedelia biflora is a herbaceous plant that thrives in tropical climates [4] and emperically has a property as a wound and ulcer medicine [5]. Several studies conducted showed its potential as antiallergic [6], antipyretic, fever and pain relievers [7] and analgesic [9] and could accelerate the healing of contusions [4]. Wedelia plants contain alkaloid compounds, terpenoids, triterpenoids and flavonoids [9-10]. Wedelia leaf extract does not cause blood and nerve disorders [11]. So far, its benefits 
as a wound medicine have not been analyzed in depth, therefore in the study will be discussed how the inflammatory phase of stage one can play a role in the wound healing process.

\section{MATERIALS AND METHODS}

\subsection{Ethical Clearance}

All experimental procedures used in this study have been reviewed and approved by the Veterinary Ethics Committee of the Faculty of Veterinary Medicine of Universitas Syiah Kuala.

\subsection{Plant Materials}

The leaf of Wedelia plants that have opened perfectly were colleted from the area of Darussalam, Banda Aceh [10]. The simplisia preparation was carried out by wet sorting, washing, slicing, deformation, and dry sorting. The extract was prepared by maceration using methanol and concentrated by evaporation using a rotary evaporator.

\subsection{Experimental Animals}

Male rats weighed 150-200 gram were purchased from the Laboratory of Pharmacology of Faculty of Veterinary Medicine, Universitas Syiah Kuala, Banda Aceh. Rats were placed in polypropylene cages ( 5 rats per cage. The room temperature was maintained at 35-37 ${ }^{\circ} \mathrm{C}$ and the lighting was set 12 hours bright and 12 hours dark. All rats were acclimated for 1 week, and fed with T-1 pellets (Repho, Surabaya). Drinking water was given ad libitum.

\subsection{Treatment}

Rats were randomly divided into 4 groups consisting of $\mathrm{P} 0$ as negative control, $\mathrm{P} 1, \mathrm{P} 2$ and $\mathrm{P} 3$ as treatment groups. All rats were firstly anaesthetized by EMLA and given the contusions by pressing the base area of the tail by doyen intestinal forceps size $23 \mathrm{~cm}$ with a degree of 1 ratchet pressing on the handle for 1 minute 30 seconds. Treatments given were topical application of aquadest (P0) and methanol extract of W. biflora leaf of $10 \%$ (P1), $20 \%$ (P2), and 40\% (P3) once a day for 8 consecutive days. Observations on the discoloration and size of contusions were carried out every day whereas blood sampling was conducted on day 1,5 , and 8 . Area of contusions (length $\mathrm{x}$ width) were measured using calipers. Blood hematology was determined using digital hematology analyzer at the Laboratory of Clinic Research, Banda Aceh

\subsection{Statistical Analysis}

Data of platelet count and their relationship with contusions size were analyzed with Analysis of variace (ANOVA), followed by Duncan Test and correlation test. The analysis was done using SPPSS software version 23 for Windows with a significant value of 0.05 .

\section{RESULTS}

The platelet count was measured on day 1, 5 and 8 . The results showed each group showed an increase in the number of platelet in line with the increase in treatment duration (Table 1).

The results of clinical evaluation based on the size of contusions area showed that the healing of process in the P3 was faster compared to those in other groups (Figure 1). On the first day of healing the size of contusions in general looked the same, but showed the difference on the $5^{\text {th }}$ and $8^{\text {th }}$ days. On the 8 th day the area of contusions in $\mathrm{P} 3$ was $0.17 \mathrm{~cm}$, much smaller than those in P0 $(6.5 \mathrm{~cm}), \mathrm{P} 1(0.89 \mathrm{~cm})$, and P2 $(0.81$ $\mathrm{cm})$. It appears that the extract of Wedelia leaf has the ability to accelerate the healing of contusions.

Table 1. Platelet numbers in contusion induced rats treated with $E$. biflora leaf extract

\begin{tabular}{|l|l|l|l|}
\hline \multirow{2}{*}{ Treatment } & \multicolumn{3}{|l|}{ Platelet Count $\left(10^{3} / \mu \mathrm{L}\right)$} \\
\cline { 2 - 4 } & Day 1 & Day 5 & Day 8 \\
\hline P0 & 927 & $1,117.6$ & 1.288 \\
\hline P1 & 902.6 & 1115.6 & 1190 \\
\hline P2 & 1105.6 & 1359 & 1450 \\
\hline P3 & 1090 & 1136.3 & 1223 \\
\hline
\end{tabular}

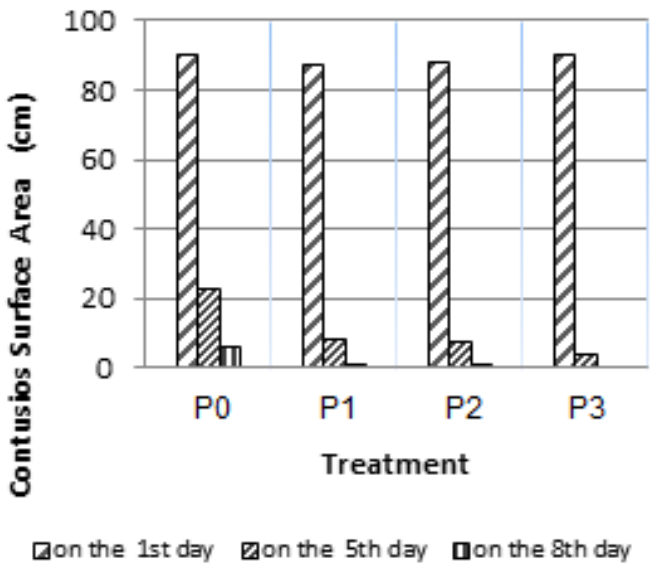

Figure 1 Wedelia biflora leaf extract can speed up healing of contusions. 
Statistical test results showed that there was a significant influence between platelet levels and drug concentration and time (day) $(\mathrm{P}<0.05)$ and there was a link between rat platelet levels and extensive contusions.

\section{DISCUSSION}

Platelets are very famous for their thrombotic roles. In addition to stopping bleeding, platelets contribute to several mechanisms and steps of wound healing and tissue repair, such as inflammation, angiogenesis, cell proliferation, and differentiation. Platelet therapic potential in wound repair makes researchers around the world look for platelet-based products and their capacity to encourage tissue regeneration, both in vitro and in vivo.

The results of this study found sinergetic effect of platelet ability with active compounds contained in Wedelia biflora leaf extract to accelerate the healing of contusions. It is well known that discoloration of contusions area is associated with the degree of wound healing. At the beginning, the area will have red color (2 days) due to the damage to hemoglobin in the extravasation of subcutaneous tissue, but hemoglobin still carries oxygen. Blood will gather in the network that elicits an inflammatory response. The color will turn bluish (2-5 days) because hemoglobins have lost oxygen (desaturated). The discoloration changes to greenish (5 day) as a result of hemoglobin metabolism by heme oxygenase to produce biliverdin. The released iron binds ferritin to produce hemosiderin. Biliverdin is then metabolized into bilirubin, resulting in yellowish color of contusions (7-10 days). The color then changes to brown (10-14 days) when hemosiderin absorbed by macrophages.

Based on the description above it appears that the process of contusions will normally get healing process for 14 days, where the healing stage begins from the edge of the bruise. In this study, Wedelia biflora leaf extract was able to accelerate with platelet for the healing process of contusions where the area of contusions is smaller compared to other group. In addition to the acceleration of contusions also seen the loss of race pain and discoloration to brown has occurred on the $8^{\text {th }}$ day (Figure 1)

This result is quite encouraging because W. biflora leaf extract is able to maintain platelet levels in controlling the healing process of contusions. However, these contusions are highly dependent on the level of pressure or blunt object impact on the tissue and how widespread the contusions size is. Therefore, the information from this research is the initial stage, which will then be continued with the next research. Research into these contusions is important in relation to the importance of legal medico case cases as an important aspect of forensic medicine.

\section{CONSCLUSION}

The initial stage was seen that Wedelia biflora leaf extract was able to accelerate the healing of contusions, but did not increase the number of platelets. However, this stage of healing needs to be reobserved with several other parameters such as the size of the contusions area, the location of contusions on the body, and age.

\section{AUTHORS' CONTRIBUTIONS}

$\mathrm{R}$ and $\mathrm{MI}$ conceptualized and designed this research. The research was carried out by $\mathrm{A}$ and $\mathrm{R}$ and also drafted, revised, and finalized the manuscript. All authors read and approved the final manuscript.

\section{ACKNOWLEDGMENTS}

We thank the Faculty of Veterinary Medicine, Universitas Syiah Kuala, for the facility provided.

\section{REFERENCES}

[1] N.A. Punchard, C.J. Whelan, I. Adcock, The Journal of Inflammation. J. Inflamm. 1(1) (2004). DOI: https://doi.org/10.1186/1476-9255-1-1.

[2] K.Y. Stokes, D.N. Granger, Platelets: A critical link between inflammation and microvascular dysfunction, J. Physiol. 590(5) (2012) 1023-1034.

DOI: 10.1113/jphysiol.2011.225417.

[3] T.O.H. Prasetyo, General concepts of wound healing, revisited. Media J. Indones. 18(3) (2009)

208-216

DOI: https://doi.org/10.13181/mji.v18i3.364

[4] Rinidar, A.M. Lucky, E. Safitri, M. Isa, The potency of Wedelia leaves (Wedelia biflora) to acelerate healing of contusion in rats (Rattus norvegicus), Proc. of the $20^{\text {th }}$ FAVA Congress \& the $15^{\text {th }}$ KIVNAS PDHI, Bali, 2018

[5] K. Heyne, Tumbuhan Berguna Indonesia. Edisi ke-2, Jakarta, Departemen Kehutanan, 1987.

[6] Rinidar, M. Isa, Sugito, The effect of Wedelia biflora leaves extracts on the inflammation caused by allergic reactions of dermatitis in mice (Mus musculus). The Proceedings of $2^{\text {nd }}$ Annual International Conference Universitas Syiah Kuala, 2(1) (2012) 434-436.

[7] A.H.A. Ali, Rinidar, T. Armansyah, A. Harris, Dasrul, Potensi ekstrak air daun sernai (Wedelia biflora) sebagai anti nyeri pada mencit (Mus musculus), JMV 10(2) (2016) 137-140. 
[8] Rinidar, T. Armansyah, T.R, A.P. Irsyad, Fraksi metanol daun sernai (Wedelia biflora) sebagai analgesik pada mencit putih (Mus musculus), JIMVET 1(1) (2017) 8-12. DOI: https://doi.org/10.21157/j.med.vet.v10i 2.4625.g3997

[9] Afnidar, Fitokimia dan uji aktivitas antibakteri ekstrak kalus tumbuhan sernai (Wedelia biflora (L) DC), JESBIO 3(4) (2014) 9-16.
[10] M. Isa, Identifikasi kandungan senyawa kimia pada Wedelia biflora dan uji bioaktivitasnya sebagai anti Plasmodium berghei. JMV 8(1) (2014) 51-55.

[11] Rinidar, M. Isa, M. Hasan, T. Armansyah TR, Blood profile and reflex righting in central pain induced rats after administration of Sernai (Wedelia biflora), Proceeding, of the $1^{\text {st }}$ International Conference on Veterinary, Animal and Enviromental Sciences 2019. 